\title{
Rethinking Federalism: Network Governance, Multi-level Governance and Australian Politics
}

\author{
Paul Fawcett and David Marsh
}

\section{Introduction}

There has been an explosion of interest in governance and multi-level governance (MLG) over the past 20 years. The literature on governance has drawn attention to the use of networked, collaborative and partnershipbased approaches, whilst the concept of MLG has combined these concerns with a related set of questions about scale, including the dispersal of decision-making authority from the local to the global level. This combination of state transformation at both the vertical and horizontal levels has proven to be particularly successful at capturing the imagination of scholars both within and beyond the European Union (EU). At the same time, the literature on Australian federalism and intergovernmental relations has shown relatively little interest in directly engaging with the concept of MLG and associated debates.

Here, we argue that the MLG literature raises new and important research questions that currently remain relatively under-explored in the literature on Australian federalism. In our view, these questions merit further consideration because they have a potentially important impact on how we understand the changing nature of intergovernmental relations and 
the future of federalism more broadly conceived. It therefore seems appropriate to examine what insights can be drawn from this literature and the extent to which key concepts and ideas can be applied, with suitable adaptations, to reflect the particularities of the Australian context.

It is worth briefly noting at the outset that we are not arguing that one set of ideas or concepts must 'replace' another. Our main argument is that an MLG perspective can build on federalism's central focus on federal-state relations by drawing attention to the different scales and network of actors that play an increasingly active role in the policymaking process. As such, the literature on MLG provides one possible way of examining the trends associated with governance and their potential impact on federal systems.

This chapter is divided into three substantive sections. We begin by locating the concept of MLG in discussions about the changing nature of governance. Our argument is that MLG and federalism are not mutually exclusive; it is about federalism and MLG, rather than federalism or MLG. We then examine the literature on Australian federalism and compare it briefly with recent Canadian work, because much greater interest has been shown in applying the MLG concept there than in Australia. The third section extends this analysis by examining the extent to which the trends associated with MLG are evident in Australia. We draw on various empirical examples, which confirm that, whilst there may not be much direct discussion of MLG in Australia, there is a great deal of indirect discussion of its key features, challenges and concerns. In the conclusion, we briefly outline how some of these features, challenges and concerns could be explored within a federal context.

\section{What is multi-level governance?}

MLG is a concept that has gained popularity beyond its original application in EU studies (e.g. Stephenson 2013; Enderlein et al. 2010). It is now widely used to refer to vertical and horizontal changes within the state under the influence of such factors as globalisation, regionalisation and devolution, networks, privatisation and public-private partnerships respectively (Büchs 2009). These changes have generated particular interest within the EU due to its sui generis nature, but their impact is by no means limited to it. 
This has prompted scholars to use the MLG concept in other fields such as global governance and federal studies. Kay, in Chapter 2, describes MLG as a 'composite construction' that 'brings key governance insights from studies of non-hierarchical, informal and continuous interactions between public organisations into federal studies' and 'identifies a particular governance problem in federal systems - multi-level policy coordination - within broader governance debates'. He further develops this baseline definition with reference to Hooghe and Marks's (2010) distinction between Types I and II of MLG.

Daniell and Kay have already outlined the key features of Type I and Type II MLG in their opening chapter, so we will not repeat these here. We only note that Hooghe and Marks (2010) argue that Type I and Type II MLG generate three forms of 'bias'. They argue that Type I MLG serves an intrinsic rather than extrinsic community (e.g. communities with a national, regional, local, religious or ethnic identity); prioritises voice through political deliberation in conventional liberal democratic institutions with high barriers to exit over jurisdictions that are organised around delivering a public good through a more voluntary membership; and privileges conflict articulation through structured political contestation and party competition on a left/right axis over consensus through specific purpose jurisdictions. As Daniell and Kay note in Chapter 1, these characteristics mean that some policy sectors maybe more susceptible to one form of MLG compared with another. It is also more likely that Type II arrangements will vary in their durability, fixity and geographical scope than Type I arrangements. This makes the distinction between Type I and Type II MLG particularly useful because it acts as a 'point of departure' for examining the extent to which each type coexists with the other in particular settings, how they coexist and why particular governance arrangements have evolved in the way that they have (e.g. Sutcliffe 2012). Most studies that have examined these questions have concurred with Hooghe and Marks's (2010: 23) conclusion that:

Type II governance tends to be embedded in legal frameworks determined by Type I jurisdictions. The result is a large number of relatively selfcontained, functionally differentiated Type II jurisdictions alongside a number of general-purpose, nested Type I jurisdictions.

This suggests that prevailing Type I arrangements will likely have an impact on Type II arrangements. By drawing attention to the role played by Type II arrangements, however, MLG also destabilises some of the 
more conventional analyses and concepts in the literature on federalism. In particular, it draws our attention to three themes that are common to most studies of MLG: a move beyond formal institutions, a multi-scalar focus and a more networked approach (Torfing et al. 2012).

\section{Beyond formal institutions}

One implication of the above discussion is that MLG pushes us to think beyond formal institutions, including the state, constitutional mandates, fiscal federalism and the formal agreements that exist between different levels of government. In particular, MLG blurs the distinctions found in more traditional approaches to intergovernmental relations, such as jurisdiction, subordination and control, by suggesting that these relationships are often less ordered than constitutional rules dictate. Institutions therefore have an important role in structuring a political system, but they may be less important than in the past, particularly in situations where the very nature of a public policy problem challenges long-held distinctions, such as those between the local, national and global, or the state and civil society. In such situations, agents may seek to bypass or work around existing institutional arrangements. This is clear in the growing role played by transnational and domestic private governance systems in areas such as forestry, coffee, food production, tourism and fisheries (e.g. Cashore 2002). More broadly, the growth of voluntary forms of self-regulation can also be taken as typical of this development (e.g. Provost 2012).

This suggests that studying patterns of interaction between agents within a political system (broadly defined) is as important as studying the distribution of power and resources within formal institutional arrangements. This more actor-centred perspective encourages an analysis of the interplay between multiple governmental tiers and the participation of sub-national units, organised interests and actors from the public and private sector in the policymaking process. It also encourages a view from the 'bottom up' in which a greater emphasis is placed on studying policymaking and its implementation 'on the ground' (e.g. Agranoff 2004; McGuire 2006). 


\section{A multi-scalar focus}

It follows from the previous section that MLG approaches also have a more multi-scalar focus, placing greater emphasis on how different levels of government and governance interact with one another in a fluid relationship, rather than on the 'nested' hierarchy that has characterised the way in which intergovernmental relations have been classically analysed. In doing so, MLG approaches have drawn on arguments about the 'rescaling of the state', the 'politics of scale' and the 'political organisation of space' that have examined how power is deployed and experienced in different spatial arrangements beyond the nation state (for a review, see Brenner 2009).

A multi-scalar focus has also pushed those using an MLG approach to think about new levels of government and governance. This includes the interplay that exists between the domestic and international levels, as well as sub-national units, such as regional, local, city and community-based governance structures. In other words, there is a broader focus on the horizontal and vertical governmental and non-government policymaking structures operating at different levels and across different sectors. This is based on a recognition that resources, authority and agency flow between different institutional levels and networks. An examination of how and where actors at different levels and scales intersect with one another is, therefore, a crucial aspect of any MLG account.

\section{A networked approach}

The third implication from the previous discussion is that networks and networked interactions become an important focus of study. This follows from the more process-orientated and multi-scalar approach outlined above, in which networks provide agents with the opportunity to share knowledge, combine resources and generate political leadership through bargaining. This more horizontal orientation has been a particular focus within the literature on policy networks, which has developed a range of typologies to examine the different types of relationships that exist between state actors and private actors and their impact on the policymaking process (e.g. Marsh 1998; for recent applications, see Daugbjerg and Fawcett 2017; Fawcett and Daugbjerg 2012; Osborne 2010, Part V). This can include variation in the 'rules of the game', as well as the norms that underpin a network. A key distinction is often made in this literature between policy communities, which are tight, closed, highly integrated and 
highly institutionalised networks, and issue networks, which are weakly integrated, open and relatively dispersed. Policy communities often resist change, whereas issue networks often struggle to reach agreement due to the lack of consensus that exists between its members on basic policy objectives, policy principles and procedures.

The growth of networks may, however, also be used to highlight the broader disaggregation of the state. For example, many of the studies that have examined EU governance use networks to criticise existing concepts and applications for being too state-centric (e.g. Kohler-Koch and Rittberger 2006). Here, networks are used to refer to the multiplicity of linkages and interactions that exist between a large and wide number of actors from across all levels of government and society. For example, Sørenson and Torfing (2007: 3-4) have argued that:

policy, defined as the attempt to achieve a desired outcome, is a result of governing processes that are no longer fully controlled by the government, but subject to negotiations between a wide range of public, semi-public and private actors, whose interactions give rise to relatively stable patterns of policy making that constitute a specific form of regulation, or mode of coordination.

Both of these uses of the network concept are present in the literature on MLG. Whilst these uses differ from one another in important respects, they nevertheless agree that networks present some common challenges in a more multi-scalar environment. This is particularly the case where networks privilege the priorities of their network over the priorities of any particular scale, do not align with pre-existing scalar boundaries and often act across multiple scales, due to their flexibility to respond to problems that cut across boundaries. This often results in a complex patchwork of networks that intersect at a variety of different scales with other networks that share similar, but not necessarily identical, concerns.

\section{Multi-level governance and federalism}

The preceding section identified some of the core characteristics of the literature on MLG. We now consider what sort of contribution it can make to the scholarship on federalism. Various metaphors and descriptive models have been used to capture different types of federalism. Federal systems have been described as cooperative, coordinative, polycentric, polyphonic, coercive, pragmatic and fuzzy. Some of these labels have 
more affinity with the concept of MLG than others, but what they share is the view that federalism is an ongoing project, as much as it is a formal arrangement for allocating authority and responsibilities (Clarke 2007). The more recent interest in MLG can be seen as a further extension of these concerns, although it is a development that has not been universally welcomed (e.g. Hueglin 2013).

In the next section, we briefly review the literature on federalism in Australia, emphasising that there is an overwhelming focus on the formal institutions of the state. We subsequently examine how the concept of MLG has been used beyond the EU. We focus on Canada, where more interest has been shown in how the MLG concept could be applied in a federal context. This is important as it suggests that a greater engagement with the Canadian literature on MLG may help to answer key questions, such as how and why the trends associated with MLG are having a more, or less, significant impact in Australia, compared with elsewhere.

\section{Studying Australian federalism}

Federalism has been a significant factor in Australian democracy for over a century, but it was not until mid-century that the academic study of Australian federalism began to gain ground (Fenna 2009). This can be partly explained by the early intellectual influence of British political studies, which understood government in terms of the Westminster Model. Australia's federal features were viewed with scepticism from this perspective due to the checks and balances that it imposed on the national level of government and its institutional and normative base in the American system of government (Parkin 2003). In these early days, Australia's federal inheritance was ignored, seen as an unwelcome distortion or regarded as fundamentally incompatible with the Westminster Model (Rhodes 2005). This has been reflected in the strongly normative tone that is evident in much of the literature on Australian federalism, including 'profound disagreement' over its legitimacy and relevance (Fenna 2009).

Institutional and comparative accounts of Australian federalism have focused on the changing relationship between different tiers of government - in essence, variation and changes within Type I MLG, but with an overwhelming focus on federal-state interactions. This has included studies that have examined the evolution of a relatively stable and consistent set of institutional arenas (e.g. executives, legislatures and courts), key actors (e.g. politicians and senior government officials) and 
processes (e.g. electoral forces) (Clarke 2007). A similar focus is also evident in the 'central topics' that have animated the interest of scholars working on Australian federalism, including constitutional-juridical change (e.g. the constitution and constitutional change or legal decisions taken by the High Court), economic-fiscal reform (e.g. the use of tied grants or the vertical fiscal imbalance between the Commonwealth and the states) or governmental-political-administrative relations (e.g. the role of the Senate or the reform of intergovernmental processes and institutions, such as the Council of Australian Governments, COAG) (Fenna 2009: 147). These studies have noted and assessed the impact of long-standing and contemporaneous developments on the character of Australian federalism, such as the relatively high degree of concurrency in key policy domains and the trend towards centralisation (Hollander and Patapan 2007; Galligan 2008; Fenna 2012). The changing relationship between different tiers of government has, however, been the starting point for much of this scholarship.

In other words, the literature on Australian federalism has been concerned with either normative issues, such as the compatibility between federalism and responsible government, or more institutional and legal issues. More recent scholarship has tended to focus on the institutional and legal aspects of Australian federalism, but that literature has been overwhelmingly statecentric in orientation. This has led to a particular focus on 'high politics' and executive federalism, but relatively little attention towards the issues raised by the literature on MLG. For example, there is no index entry on 'governance' in either of the two more recent volumes on Australian federalism (Appleby et al. 2012; Kildea et al. 2012). Yet, federalism in Australia appears to exhibit several of the key characteristics that have been identified by the literature on MLG.

One example can be seen in Galligan's (cited in Rhodes 2005: 142) description of federalism and intergovernmental relations as 'essentially untidy', a complex 'mixing and blending' of agencies with 'governments and parts of governments competing for a share in the action' in 'a communications network rather than a chain of command'. Concurrency contributes to this complexity, as roles and responsibilities in some policy areas are shared between the Commonwealth and states. Galligan (2008: 639) argues that: 'If there were ever a bottle with separate internal compartments for Commonwealth and state powers, the genie 
escaped long ago, and has so infused major policy domains that there is no putting it back.' Moreover, the need to address issues that traverse jurisdictional boundaries is becoming ever more urgent:

Working out better arrangements and systems for intergovernmental management across jurisdictions within large policy areas is the biggest challenge facing modern Australian federalism, and is where our attention and effort should be focused. Happily, it is precisely these issues that are currently being tackled by COAG (Galligan 2008: 641).

This all contributes to an image of federalism as a 'policy matrix in which no government has a monopoly or complete authority' (Galligan, cited in Rhodes 2005: 142).

These conclusions are supported by other studies. For example, Fletcher (1991: 86-87) describes federal relations in Australia as a jurisdictional muddle ... [a] complex picture of institutions ... rather than a system of government organised into neat hierarchical functions'. Similarly, Stein and Turkewitsch (2010: 196) observe that there has been a more general shift in the literature on federalism away from descriptive models based in hierarchy towards models that have placed more emphasis on the shared or cooperative aspects of decision-making.

\section{Studying federalism beyond Australia}

It is within this context that there has been a noticeably greater openness to the concept of MLG in other jurisdictions. This has, however, worked both ways. On the one hand, EU scholars have been open to appropriating ideas, approaches and concepts in the literature on federalism. This has been noticeable in federal jurisdictions within the EU, such as Germany, as well as countries that have undergone devolution, such as the United Kingdom (e.g. Börzel and Hölsi 2003; Asare et al. 2009; Schmidt 1999; Benz and Zimmer 2010; Entwistle et al. 2012; Piattoni 2012). On the other hand, a number of studies have used MLG as a way of comparing the governance arrangements in the EU with pre-existing federal jurisdictions, particularly in the United States (e.g. Nicolaidis and Howse 2001; Menon and Schain 2007).

This transfer of ideas has also been evident in Canada where scholars have shown a particular willingness to experiment with the MLG concept. This interest is illustrated by the growing number of studies that have used 
the MLG concept to examine the governance arrangements in different policy areas, ranging from indigenous affairs and urban planning, to crossborder river disputes, immigration resettlement and climate change. ${ }^{1}$

Horak and Young's (2012) work on Canadian cities provides one example of this broader interest. Their argument is that federalism and the study of intergovernmental relations can no longer be confined to the interactions that take place between federal and provincial politicians and/or administrators. They argue that a suitably adapted version of MLG provides a more convincing fit with the changing nature of intergovernmental relations in Canada compared with the more restricted image provided by accounts grounded in executive federalism. Similarly, in reflecting on the particular public policy challenges that Canada now faces, Meekison et al. (2004: 23) have argued that:

the sort of multi-centred collaboration that is now being contemplated, and that could involve federal, provincial, municipal, Aboriginal, and foreign governments, as well as transnational institutions, will be much more complex and increasingly political than earlier federal-provincial interactions.

They also note, however, that the challenges presented by emerging forms of MLG are 'only just beginning to be addressed' (Meekison et al. 2004: 24).

We certainly agree with Meekison et al. (2004) that we are only starting to address emerging forms of MLG, but even this brief review of the literature would appear to support the argument that there has been a greater engagement with the MLG concept in Canada, compared with Australia. We recognise that there are important differences between Australia and Canada that may help to explain some of this variation, but also note the tradition of comparison between them and the fact that they share some key institutional characteristics (see Rhodes et al. 2009). At the very least, this suggests that some further examination of the key trends associated with MLG could be useful.

1 See, for example, the recent Special Issue on Federalism and MLG in Canada, in Canadian Public Administration, Volume 56, Issue 2, June 2013. 


\section{Multi-level governance in Australia}

We draw on various empirical examples in this section to further support our argument that an MLG perspective raises a number of insights that could make an important contribution to the literature on Australian federalism. We argue that, whilst there has been relatively little direct discussion about MLG in Australia, there has been a great deal of indirect discussion about MLG's key features, challenges and concerns. We illustrate our argument with examples from three areas: intergovernmental relations, sub-national governance and policymaking in environmental governance and natural resource management.

\section{Intergovernmental relations}

Intergovernmental relations in Australia continue to remain a relatively closed and secretive world in which the key actors are the Commonwealth prime minister, state premiers, portfolio ministers and their permanent officials (Painter 2001: 138). More recent scholarship has identified a trend towards a centralisation of power at the federal level, at the same time as it has been argued that federal-state relations have also become more collaborative (e.g. Hollander and Patapan 2007; O'Flynn and Wanna 2008; Jones 2010). As discussed earlier, this tension can be partly explained by the concurrency that exists in the Australian federation. For example, Hollander (2009: 141) argues that:

While the Australian federation has been subject to strong centripetal forces in Australian federalism, the states, nevertheless, have continued to play a significant role in both policy making and implementation (Parkin 2003: 106-08), and the concurrency embedded in the Australian federation means that the system has continued to exhibit characteristics of Grodzin's 'marble cake' of shared activities.

Painter (2001: 139-40) further illustrates this tension by pointing to the two fundamental, and contradictory, sets of institutional forces and rationales at work in the relationship between officials and ministers at the Commonwealth and state level:

The first set is centred on the domestic policy processes of the separate governments. It is deeply embedded in formal structures of accountability and control modelled on the Westminster system. The underlying principle of this set is command in hierarchy. In the second set, cross-jurisdictional intergovernmental networks and arenas of policy cooperation and conflict 
shape relationships. They emerge in a context characterised by power sharing and interdependence, where cooperation rather than command is the underlying organising logic of effective policy making.

He notes that challenges often emerge as actors shift between these two different logics:

Problem-solving strategies appropriate for the domestic setting are often countermanded by the rules of the game of the intergovernmental or multi-level context, and contradictions and tension may emerge that block the facilitation of joint action in the intergovernmental arena (Painter 2001: 140).

It is therefore understandable that centralisation may take place hand-inhand with what Painter (2001: 149) has described as a 'long term trend towards the diffusion and institutionalisation of more collaborative forms of coordination in the Australian federation'. A similar trend has also been identified by Fels (2008: xii), who has argued that:

Collaboration between governments could herald a new phase of federalism. If 'cooperative federalism' is about microeconomic reform and structural efficiencies, 'collaborative federalism' is about sharing intent, sharing goals and agreeing on delivery responsibilities. This new phase of federalism is likely to focus on social policies, national security and bio-security, the environment, infrastructure and communication. Above all, it is likely to dispense with the notion that 'government knows best', replacing it not just with intergovernmental agreements, but with community involvement in policy design and delivery. It could be more messy, but also more realistic and more results-based.

Fels's argument suggests that there may need to be more engagement with Type II forms of MLG, whereas most of the literature on intergovernmental relations has focused primarily on Type I MLG. As Fels suggests, such an endeavour would involve not only intergovernmental agreements, but also greater community involvement in policy design and delivery. Any attempts to move in this direction, however, will clearly take place against the backdrop of the competing logics described by Painter (2001).

\section{Sub-national governance}

There is a significant literature that has examined sub-national governance structures in Australia, such as local government, regional governance structures, cities, municipalities and local communities (e.g. Brown 
and Bellamy 2007; Jones 2008; Everingham et al. 2009; Acuto 2012); however, the literature on federalism and intergovernmental relations has tended to analyse these arrangements as either discrete entities or in the shadow of federal-state relations. At the same time, sub-national units have also been increasingly identified as an appropriate scale for tackling various policy issues. For example, the important role that regions play in certain policy areas supports Galligan's (2008: 618) argument that:

regionalism is alive and well at the sub-State level for certain governance purposes and policy delivery regimes, and can be a preferred identifier for groupings of people concerned with or responding to certain issues.

Brown $(2009,2012)$ has gone somewhat further and argued that regions form an important part of the day-to-day political culture and practice of Australian citizens. This view is supported by Taylor's (2012: 507) study of the wheatbelt region of Western Australia in which he argues that 34 rural local governments were able to 'buffer state intervention and improve the effectiveness of their own cooperative planning and management activities for sustainable development' by adopting a defensive posture towards a state-led program of regionalisation for economic development and natural resource management.

These points are also illustrated by Brown and Bellamy's (2010) case study of the rural and remote region of central west Queensland in which at least 21 different regional bodies, programs, committees and communitybased groups exist across a wide variety of policy areas from regional development, transport and integrated planning, to tourism, indigenous welfare and health and social services. Brown and Bellamy (2010) note the patchwork, informal and impermanent arrangements that exist in central west Queensland in which many services are delivered by project and network-based groups or public-private partnerships that involve a broader range of actors from the public, private and voluntary sectors. They argue that this has generated some challenges, including shortages in human capital, wider intergovernmental conflict, financial sustainability, misalignment between policy scales and responsibilities, legitimacy deficits and difficulties in securing sufficient policy capacity (Brown and Bellamy 2010: 180). They also noted the multiple, and sometimes blurred, spatial, functional and sectoral boundaries that can exist between different regional identifiers (Brown and Bellamy 2010: 172-75). Differences at this level existed not only between state and Commonwealth governments, but also between departments within any one given level of government. 
They also note, however, that the partnership arrangements that exist in central west Queensland have also provided it with the flexibility and responsiveness to deal with various policy issues (Brown and Bellamy 2010: 190-91). So, whilst many of the participants in their study expressed concern that the system was 'supported only by weak regional institutional frameworks', they also noted the advantages that this brought. What this suggests is a struggle in central west Queensland between a desire to move further towards more institutionalised, Type I arrangements, combined with a concern that this would lead to a loss of flexibility and capacity to adapt to the more partnership- and project-based strategy found in Type II MLG arrangements. As Brown and Bellamy (2010: 191) note, the interviewees in their study:

revealed little desire to sacrifice flexibility and informality, even when participants recognized the various signs of institutional weakness in the regional governance system, on the basis that this could limit their effective capacity to translate adaptive processes into outcomes.

Indeed, Brown and Bellamy's findings demonstrate how the participants in their study are balancing the various virtues and vices of Type I and Type II MLG that were discussed in the opening section of this chapter.

\section{MLG and policymaking}

MLG has also been used to examine the policymaking process, particularly in the literature on environmental governance and natural resource management (e.g. Morrison 2007; Lockwood et al. 2009; Daniell et al. 2011). In many instances, these difficulties can be located at the interface between Type I and Type II MLG. For example, Bellamy (2007: 104-05) argues that natural resource management in Australia increasingly involves:

a complex system of multiple 'nested' or polycentric decisionmaking arrangements (versus being neatly hierarchical) being carried out concurrently across a range of political decision-making levels (e.g. national, state, region, local) and horizontally across a fragmented array of territorial and sectoral areas ... This system is continually evolving at all political and sectoral levels ... At each level of this complex multilayered and polycentric system, there are different emergent properties and problems to be addressed. 
Similarly, Bulkeley, in a series of single and co-authored contributions, has identified the emergence of a complex set of governance arrangements around climate change policy in Australia at the city/municipal level (e.g. Bulkeley 2005; Betsill and Bulkeley 2006; Bulkeley and Betsill 2013; see also Jones 2012, 2013). For example, Betsill and Bulkeley (2006: 151) argue that the inherently multi-level nature of the governance of climate change policy is leading to an active reconfiguration and renegotiation of the roles and responsibilities of state and non-state actors:

While the nation-state may be responsible for legitimating and alleviating climate risks, this is a task that it cannot complete without addressing the source of risks (energy use) and without the involvement of the institutions and agents responsible for that use (industries and communities). In turn, non-state actors, which operate at different scales traditionally across discrete policy sectors, share responsibility with the state for defining problems and implementing solutions.

Bulkeley and Betsill (2013) argue that this renegotiation of roles and responsibilities is illustrated by the active role that several cities in Australia have played in various transnational municipal networks, such as the C40 network, the International Council for Local Environmental Initiatives' (ICLEI) Cities for Climate Protection (CCP) program and Climate Alliance. For example, they show how the city of Melbourne has developed a coordinated and strategic approach to climate change, despite the fragmented nature of local governance. Bulkeley and Betsill (2013) argue that Melbourne has been able to do this by providing strategic direction (e.g. the 2002 Victorian greenhouse strategy and the Zero Net Emissions by 2020 - Strategy Update), promoting Greenpower energy, supporting the ICLEI CCP program in regional and rural Australia and helping local councils to form partnerships known as regional greenhouse alliances. ${ }^{2}$

Bulkeley's overall argument is that these developments illustrate new spheres of authority that are not bound to a particular scale, but which are having a direct effect on the governance of climate change in various cities worldwide (e.g. Bulkeley 2005). She argues that these relatively new forms of Type II MLG in Australia also help illustrate at least three

2 Examples include Central Victoria Greenhouse Alliance, Eastern Alliance for Greenhouse Action, Gippsland Climate Change Network, Goulburn Broken Greenhouse Alliance, North East Greenhouse Alliance, the Northern Alliance for Greenhouse Action, the South East Councils Climate Change Alliance and Western Alliance for Greenhouse Action (see www.naga.org.au/alliances.html). 
points. First, cities are playing an important role in addressing climate change in ways that nation-states have often failed to fully appreciate. Second, cities and local authorities can effectively bypass the nation-state, even when the actions that they take may contradict those that are being pursued by the national government. Third, cities and local governments have taken on functions that are typically associated with nation-states, such as the development of norms, rules for compliance and mechanisms for reporting and monitoring emissions. Betsill and Bulkeley (2006: 152) conclude that:

This suggests that political power and authority lie not only with nationstates, but can accrue to transnational networks operating through a different form of territoriality.

\section{Conclusion}

This chapter has asked whether it is possible to draw ideas from a concept, such as MLG, beyond the particular context within which it was originally developed. We have argued that there appear to be some advantages in examining Australian federalism from an MLG perspective but it is obviously important that it is done with considerable caution.

The considerable differences that exist between the EU, as an emerging supra-national polity, and the federal system of government that exists in Australia, is one clear reason why it is necessary to proceed with caution. Most federal systems do not have a genuinely autonomous supra-national level of government like the EU; there are important differences in institutional architecture between the EU and Australia and the circumstances that gave rise to the federation in Australia are clearly different from those that gave rise to the EU. Bakvis (2013) underscores this point with reference to the Canadian context. He argues that, whilst non-hierarchical modes of coordination are used in Canada, hierarchy plays a more critical role in Canada than in the EU, due to its propensity for top-down control, the government's lack of willingness to engage civil society and a closed and elite-driven form of executive federalism:

In the Canadian federation hierarchy plays a critical role, but not in direct relations between governments. Rather, as argued, hierarchy is found mainly within governments, with executive dominance the primary outcome, thereby affecting relations between governments: interactions 
tend to be limited to those between governments (interstate federalism), mainly at a senior level and at the expense of inclusive networks and connections with civil society (Bakvis 2013: 215).

We have made a similar point when examining the nature of intergovernmental relations in Australia. So, factors such as those identified by Bakvis will clearly have an impact on the extent to which Type II MLG develops in Australia, given that these governance arrangements will be embedded within the legal frameworks and norms determined by Type I jurisdictions.

At the same time, we have also detailed several instances where Type I MLG is coexisting with Type II MLG in Australia. This raises important questions about how differences in institutional structure shape the extent to which Type II MLG emerges and how Type II MLG intersects and coexists with Type I MLG. The brief examples that we have provided suggest that this will vary across policy areas and between national contexts, but developing a better understanding of what drives this variation is clearly an important area for further research.

We have argued that greater engagement with the literature on MLG could act as a good starting point for this work. In particular, we have shown how taking an MLG perspective has opened up new lines of enquiry in other countries that share Australia's federal system of government. The different examples of Type II MLG that we have discussed suggest that similar trends are taking place in Australia. In our view, further research is now required in order to better understand how Type I MLG intersects and coexists with Type II MLG in Australia, including the effectiveness and legitimacy of such arrangements. The chapters in this volume are an important step in that direction.

\section{References}

Acuto, M. (2012). Ain't about Politics? The Wicked Power-Geometry of Sydney's Greening Governance. International Journal of Urban and Regional Research, 36(2): 381-99. doi.org/10.1111/j.1468-2427. 2011.01063.x

Agranoff, R. (2004). Researching Intergovernmental Relations. Journal of Public Administration Research and Theory, 14(4): 443-46. doi.org/10.1093/jopart/muh030 
Appleby, G., Aroney, N. \& John, T. (eds) (2012). The Future of Australian Federalism. Cambridge University Press, Melbourne.

Asare, B., Cairney, P. \& Studlar, D.T. (2009). Federalism and Multilevel Governance in Tobacco Policy: The European Union, the United Kingdom, and devolved UK institutions. Journal of Public Policy, 29(1): 79-102. doi.org/10.1017/S0143814X09000993

Bakvis, H. (2013). 'In the shadows of hierarchy': Intergovernmental governance in Canada and the European Union. Canadian Public Administration, 56(2): 203-18. doi.org/10.1111/capa.12014

Bellamy, J. (2007). Adaptive Governance: The challenge for regional natural resource management. In: Brown, A.J. \& Bellamy, J.A. (eds) Federalism and Regionalism in Australia: New Approaches, New Institutions? ANU E Press, Canberra, pp. 119-34.

Benz, A. \& Zimmer, C. (2010). The EU's Competences: The 'vertical' perspective on the multilevel system. Living Reviews in European Governance, 5(1), www.europeangovernance-livingreviews.org/Articles/ lreg-2010-1/download/lreg-2010-1Color.pdf [Accessed: 01/06/14].

Betsill, M. \& Bulkeley, H. (2006). Cities and the Multilevel Governance of Global Climate Change. Global Governance, 12(2): 141-59.

Börzel, T.A. \& Hösli, M. (2003). Brussels between Bern and Berlin. Comparative Federalism Meets the European Union. Governance, 16(2): 179-202. doi.org/10.1111/1468-0491.00213

Brenner, N. (2009). Open Questions on State Rescaling. Cambridge Journal of Regions, Economy and Society, 2(1): 123-39. doi.org/10.1093/ cjres/rsp002

Brown, A.J. (2009). Thinking Big: Public opinion and options for reform of Australia's federal system. Public Policy, 4(1): 30-50.

- (2012). Mapping Federal Political Culture and Support for Political Reform in the World's First 'Top-Down' Federation: the strange case of Australia. Paper Presented at the Triennial Meeting of the International Political Science Association, 8-11 July, Madrid, Spain.

Brown, A.J. \& Bellamy, J.A. (eds) (2007). Federalism and Regionalism in Australia: New Approaches, New Institutions? ANU E Press, Canberra. 
. (2010). In the Shadow of Federalism: Dilemmas of institutional design in Australian rural and remote regional governance. The Australasian Journal of Regional Studies, 16(2): 151-81.

Büchs, M. (2009). Examining the Interaction Between Vertical and Horizontal Dimensions of State Transformation. Cambridge Journal of Regions, Economy and Society, 2(1): 35-49. doi.org/10.1093/cjres/ rsn026

Bulkeley, H. (2005). Reconfiguring Environmental Governance: towards a politics of scales and networks. Political Geography, 24(8): 875-902. doi.org/10.1016/j.polgeo.2005.07.002

Bulkeley, H. \& Betsill, M.M. (2013). Revisiting the Urban Politics of Climate Change. Environmental Politics, 22(1): 136-54. doi.org/ 10.1080/09644016.2013.755797

Cashore, B. (2002). Legitimacy and the Privatization of Environmental Governance: how non-state market-driven (NSMD) governance systems gain rule-making authority. Governance, 15(4): 503-29. doi.org/10.1111/1468-0491.00199

Clarke, S.E. (2007). 'Thinking Federally' from a Governance Perspective. In: Pagano, M.A. \& Leonardi, R. (eds) The Dynamics of Federalism in National and Supranational Political Systems. Palgrave Macmillan Houndmills, pp. 55-85. doi.org/10.1057/9780230625433_4

Daniell, K.A., Máńez Costa, M.A., Ferrand, N., Kingsborough, A.B., Coad, P. \& Ribarova, I.S. (2011). Aiding Multi-level Decision-making Processes for Climate Change Mitigation and Adaptation. Regional Environmental Change, 11(2): 243-58. doi.org/10.1007/s10113-0100162-0

Daugbjerg, C. \& Fawcett, P. (2017). Metagovernance, Network Structure, and Legitimacy: Developing a heuristic for comparative governance analysis. Administration \& Society, 49(9): 1223-1245. doi.org/ $10.1177 / 0095399715581031$

Enderlein, H., Wälti, S. \& Zürn, M. (eds) (2010). Handbook on Multilevel Governance, Edward Elgar, Cheltenham. 
Entwistle, T., Downe, J., Guarneros-Meza, V. \& Martin, S. (2012). The Multi-level Governance of Wales: Layer cake or marble cake? British Journal of Politics and International Relations, 16(2): 310-25. doi.org/10.1111/j.1467-856X.2012.00541.x

Everingham, J., Cheshire, L. \& Lawrence, G. (2009). Regional Renaissance? New forms of governance in nonmetropolitan Australia. Environment and Planning C: Government and Policy, 24(1): 139-55. doi.org/10.1068/c47m

Fawcett, P. \& Daugbjerg, C. (2012). Explaining Governance Outcomes: Epistemology, network governance and policy network analysis. Political Studies Review, 10(2): 195-207. doi.org/10.1111/j.14789302.2012.00257.x

Fels, A. (2008). Foreword: Network governance and collaboration to improve outcomes. In: O'Flynn, J. \& Wanna, J. (eds) Collaborative Governance: A New Era of Public Policy in Australia? ANU E Press, Canberra, pp. xi-xiii.

Fenna, A. (2009). Federalism. In: Rhodes, R.A.W. (ed.) The Australian Study of Politics. Palgrave, Houndmills, pp. 146-59. doi.org/ 10.1057/9780230296848_11

- (2012). Centralising Dynamics in Australian Federalism. Australian Journal of Politics and History, 58(4): 580-90. doi.org/ 10.1111/j.1467-8497.2012.01654.x

Fletcher, C. (1991). Rediscovering Australian Federalism by Resurrecting Old Ideas. Australian Journal of Political Science, 26(1): 79-94. doi.org/10.1080/00323269108402137

Galligan, B. (2008). Processes for Reforming Australian Federalism. UNSW Law Journal, 31(2), 617-42.

Hollander, R. (2009). Rethinking Overlap and Duplication: Federalism and environmental assessment in Australia, Publius, 40(1): 136-70. doi.org/10.1093/publius/pjp028

Hollander, R. \& Patapan, H. (2007). Pragmatic Federalism: Australian federalism from Hawke to Howard. Australian Journal of Public Administration, 66(3): 280-97. doi.org/10.1111/j.14678500.2007.00542.x 
Hooghe, L. \& Marks, G. (2010). Types of multi-level governance. In: Enderlein, H., Wälti, S. \& Zürn, M. (eds) Handbook on Multilevel Governance. Edward Elgar, Cheltenham, pp. 17-31. doi.org/ $10.4337 / 9781849809047.00007$

Horak, M. \& Young, R. (eds) (2012). Sites of Governance: Multilevel Governance and Policy Making in Canada's Big Cities. McGill-Queen's University Press, Montreal and Kingston.

Hueglin, T.O. (2013). Comparing federalisms: variations or distinct models? In: Benz, A. \& Broschek, J. (eds) Federal Dynamics: Continuity, Change, \& the Varieties of Federalism. Oxford University Press, pp. 2747. doi.org/10.1093/acprof:oso/9780199652990.003.0002

Jones, S. (2008). Can Australian Local Governments have a Role in Local Economic Development? Three cases of evidence. Urban Policy and Research, 26(1): 23-38. doi.org/10.1080/08111140701606785

- _. (2010). The National Renewable Energy Target: An example of post-Machiavellian policy-making? Australian Journal of Public Administration, 69(2): 165-77. doi.org/10.1111/j.1467-8500.2010. 00678.x

- - (2012). A Tale of Two Cities? Climate Change Policies in Vancouver and Melbourne - barometers of cooperative federalism? International Journal of Urban and Regional Research, 36(6), 1242-67. doi.org/10.1111/j.1468-2427.2011.01083.x

. (2013). Climate Change Policies of City Governments in Federal Systems: An analysis of Vancouver, Melbourne and New York City. Regional Studies, 47(6): 974-92. doi.org/10.1080/00343404.2011. 585150

Kildea, P., Lynch, A. \& Williams, G. (eds) (2012). Tomorrow's Federation: Reforming Australian Government. The Federation Press, Sydney.

Kohler-Koch, B. \& Rittberger, B. (2006). The 'Governance Turn' in EU Studies. JCMS: Journal of Common Market Studies, 44(s1): 27-49.

Lockwood, M., Davidson, J., Curtis, A., Stratford, E. \& Griffith, R. (2009). Multi-level Environmental Governance: Lessons from Australian natural resource management. Australian Geographer, 40(2), 169-86. doi.org/10.1080/00049180902964926 
Marsh, D. (ed.) (1998). Comparing Policy Networks, Open University Press, Buckingham.

McGuire, M. (2006). Intergovernmental Management: A view from the bottom. Public Administration Review, 66(5): 677-79. doi.org/ 10.1111/j.1540-6210.2006.00632.x

Meekison, P.J., Telford, H. \& Lazar, H. (2004). The Institutions of Executive Federalism: Myths and realities. In: Meekison, P.J., Telford, H. \& Lazar, H. (eds) The State of the Federation 2002: Reconsidering the Institutions of Canadian Federalism. McGill-Queen's University Press, Montreal and Kingston, pp. 3-34.

Menon, A. \& Schain, M.A. (eds) (2007). Comparative Federalism: The European Union and the United States in Comparative Perspective. Oxford University Press.

Morrison, T.H. (2007). Multiscalar Governance and Regional Environmental Management in Australia. Space and Polity, 11(3): 227-41. doi.org/10.1080/13562570701811551

Nicolaidis, K. \& Howse, R. (eds) (2001). The Federal Vision. Legitimacy and Levels of Government in the United States and the European Union, Oxford University Press.

O’Flynn, J. \& Wanna, J. (eds) (2008). Collaborative Governance: A New Era of Public Policy in Australia. ANU E Press, Canberra.

Osborne, S.P. (ed.) (2010). The New Public Governance? Routledge, London.

Painter, M. (2001). Multi-level Governance and the Emergence of Collaborative Federal Institutions in Australia. Policy \& Politics, 29(2): 137-50. doi.org/10.1332/0305573012501260

Parkin, A. (2003). The States, Federalism and Political Science: A fiftyyear appraisal. Australian Journal of Public Administration, 62(2): 10112. doi.org/10.1111/1467-8497.00329

Piattoni, S. (2012). Federalism and Its Competitors: Which template for contemporary Europe? L'Europe en Formation, 363(1): 9-20. doi.org/ 10.3917/eufor.363.0009 
Provost, C. (2012). Governance and Voluntary Regulation. In: Levi-Faur, D. (ed.) The Oxford Handbook of Governance. Oxford University Press, pp. 554-68. doi.org/10.1093/oxfordhb/9780199560530.013.0039

Rhodes, R.A.W. (2005). Australia: The Westminster model as tradition. In: Patapan, H., Wanna, J. \& Weller, P. (eds) Westminster Legacies: Democracy and Responsible Government in Asia and the Pacific. UNSW Press, Sydney, pp. 129-52.

Rhodes, R.A.W., Wanna, J. \& Weller, P. (2009). Comparing Westminster. Oxford University Press. doi.org/10.1093/acprof:oso/ 9780199563494.001 .0001

Schmidt, V.A. (1999). European Federalism and its Encroachment on National Institutions. Publius, 29: 19-44. doi.org/10.1093/ oxfordjournals.pubjof.a030012

Sørenson, E. \& Torfing, J. (2007). Introduction: Governance network research: towards a second generation. In: Sørenson, E. \& Torfing, J. (eds) Theories of Democratic Network Governance. Palgrave, Houndmills, pp. 1-24. doi.org/10.1057/9780230625006_1

Stein, M.B. \&Turkewitsch, L. (2010). Multi-level Governance in Canadian and American Intergovernmental Relations. In: Enderlein, H., Wälti, S. \& Zürn, M. (eds) Handbook on Multi-level Governance. Edward Elgar, Cheltenham, pp. 184-200. doi.org/10.4337/9781849809047.00018

Stephenson, P. (2013). Twenty Years of Multi-level Governance: Where does it come from? What is it? Where is it going? Journal of European Public Policy, 20(6): 817-37. doi.org/10.1080/13501763.2013.781818

Sutcliffe, J.B. (2012). Multi-level Governance in a Canadian Setting: The reform of the Detroit River border crossing. Regional and Federal Studies, 22(2): 141-58. doi.org/10.1080/13597566.2012.668137

Taylor, B.M. (2012). Regionalism as Resistance: Governance and identity in Western Australia’s wheatbelt. Geoforum, 43(3): 507-17. doi.org/ 10.1016/j.geoforum.2011.11.004

Torfing, J., Peters, B.G., Pierre, J. \& Sørenson, E. (2012). Interactive Governance Advancing the Paradigm. Oxford University Press. doi.org/ 10.1093/acprof:oso/9780199596751.001.0001 
This text is taken from Multi-level Governance: Conceptual challenges and case studies from Australia, edited by Katherine A. Daniell and Adrian Kay, published 2017 by ANU Press, The Australian National University, Canberra, Australia.

dx.doi.org/10.22459/MG.11.2017.03 